\title{
気液二相流の流動様式の簡易遷移モデル*
}

$$
\begin{array}{lllll}
\text { 伊 藤 } & \text { 二浩 } & \text { 二1, 井 上 } & \text { 満*2 } \\
\text { 小 澤 } & \text { 守*3, 庄 司 正 } \text { 弘 }^{* 2}
\end{array}
$$

\section{A Simplified Model of Gas-Liquid Two-Phase Flow Pattern Transition}

\author{
Koji ITO*4, Mitsuru INOUE, \\ Mamoru OZAWA and Masahiro SHOJI \\ ${ }^{* 4}$ Marine Engineering Division, Japan Coast Guard Academy, \\ 5-1 Wakaba-cho, Kure-shi, Hiroshima, 737-8512 Japan
}

\begin{abstract}
An experiment of upward gas-liquid two-phase flow was conducted in air-water iso-thermal system under atmospheric pressure. The differential pressure was measured at the fully-developed section by using a variable reluctance type transducer to classify the flow patterns and their transitions. The flow behavior was observed with a high-speed video camera. The probability density function (PDF) of the differential pressure signal was employed to identify the flow pattern. A simplified one-dimensional flow model was proposed to clarify dominant factors affecting the formation and transitions of flow patterns. The model dealt with the gas-component advection based on the spatio-temporal void fraction behaviors by considering the gas compressibility, the wake and the liquid phase redistribution mechanism. The simulation results of the model indicated four kinds of the void wave patterns (ripple-like, rectangular, distorted rectangular and uniform wave patterns) depending on gas and liquid volumetric fluxes. These void wave patterns well corresponded to the experimentally observed flow patterns. The transitions among void wave patterns agree well with Mishima-Ishii flow pattern map. The friction loss estimated by the present model coincides fairly well with Chisholm's empirical formula.
\end{abstract}

Key Words: Multi-phase Flow, Gas-liquid Two-Phase Flow, Flow Pattern and Transition, Modeling

\section{1.はじめに}

気液二相流の流動抵抗 (圧力損失) 队熱伝達の特性は 流れの様相，すなわち流動様式によって大きく異なる. したがって，流㥞式に関する研究は気液二相流におけ る基本的にして重要なものであって，周知のように流動

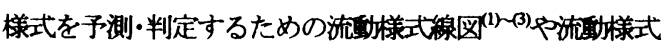
の同定法(4)(8)などがこれまでに多数報告されている.しか し，流動様式には多くの因子が関係し，その判別には研 究者の主観が介在しやすいため，実際に同定する際は注 意が必要と言われる.特に，流動様式の速移条件あるい は遷移のメカニズムについては，さまざまな見方，㧿え 方があり(2(3)，十分な理解に到っていない状況にある.

${ }^{*}$ 原稿受付 2003 年 3 月 18 月。

*1 正員, 海上保安大学校機関工学講座( - 737-8512 呉市若葉 町 5-1).

*2 正員, 東京大学大学院I学系研究科(-113-8656 東京都文 京区本郷 7-3-1).

*3 正員, 関西大学工学部(-564-8680 吹田市山手町 3-3-35).

E-mail : k-ito@ jcga.ac.jp
一方, 近年の計算機の飛羁的な発展に伴い，気液二相流 の界面槥造を数值的に捉えようとする方法 ${ }^{(100-(12)}$ ，あるい は気泡流やスラグ流のような液相中に分散した気泡を粒 子として捉え，気泡の挙動を個別に計算する方法 ${ }^{\left({ }^{(3)}\right)}{ }^{(4)}$ が 報告されており，これらの研究によって，機構論的立場 から流動様式の遷移機粠に関し新たな知見が得られる可 能性がある.

こうした従来の図式判別あるいは数值判別に対し, 本 研究は, 垂直管内を流九る等温系気液二相流の気泡流か ら吠状流までの流動様式およびその遷移が何故現れるか という基本的問題について，简易なモデルによって説明 しょうとするものである. すなわち, ランダムな気泡の 挙動や局所空間内の気泡間相互干涉（集合化，合体等) 等の機構解明には立ち入らず，流れの様相は流れ軸方向 にできるボイド率の分布パターンであると捉え，简易な モデルにより, 流動様式に対応したそれらパターンの出 現と要移の要因を統一的な考え方に基ぶいて明らかにし ている. 


\begin{tabular}{|c|c|c|}
\hline & 祀 & \\
\hline$C_{d}$ & : 抗力係数 & \\
\hline$D_{b}$ & : 気泡径 & $\mathrm{m}$ \\
\hline$D_{p}$ & : 管内径 & $\mathrm{m}$ \\
\hline$J_{f}$ & : 流れ場の平坞速度 & $\mathrm{m} / \mathrm{s}$ \\
\hline$J_{g}$ & : 気相体積流束 & $\mathrm{m} / \mathrm{s}$ \\
\hline$J_{l}$ & : 液相体積流束 & $\mathrm{m} / \mathrm{s}$ \\
\hline$G_{g}$ & : 気相の質量流束 & $\mathrm{kg} / \mathrm{m}^{2} \mathrm{~s}$ \\
\hline$g$ & : 重力加速度 & $\mathrm{m} / \mathrm{s}^{2}$ \\
\hline$H$ & : 差圧測定部長さ & $\mathrm{m}$ \\
\hline$L$ & : 管長さ & $\mathrm{m}$ \\
\hline$L_{m}$ & : 気液混合部長さ & $\mathrm{m}$ \\
\hline$P$ & : 絶対圧力 & $\mathrm{Pa}$ \\
\hline$P_{0}$ & 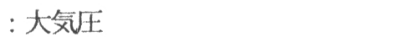 & $\mathrm{Pa}$ \\
\hline \multirow[t]{2}{*}{$q$} & \multicolumn{2}{|c|}{ : 気液混合部単位体積当たり供給される } \\
\hline & 気相質量流量 & $\mathrm{kg} / \mathrm{m}^{3} \mathrm{~s}$ \\
\hline$U$ & : 移流速度 & $\mathrm{m} / \mathrm{s}$ \\
\hline$u_{g}$ & : 流れ場に対寸る気泡上昇速度 & $\mathrm{m} / \mathrm{s}$ \\
\hline$u_{l}$ & : 流九場に対子る液相速度 & $\mathrm{m} / \mathrm{s}$ \\
\hline$u_{r}$ & : 気液の相対速度 & $\mathrm{m} / \mathrm{s}$ \\
\hline$u_{w}$ & : 引き込み速度 & $\mathrm{m} / \mathrm{s}$ \\
\hline$u_{\text {smax }}$ ' & : 後流内の最大速度欠宿 & $\mathrm{m} / \mathrm{s}$ \\
\hline$V$ & : 気相の体積 & $\mathrm{m}^{3}$ \\
\hline \multirow[t]{2}{*}{$v$} & \multicolumn{2}{|c|}{ : 気液混合部単位体積当たり供給される } \\
\hline & 気相体積流量 & $1 / \mathrm{s}$ \\
\hline$z$ & : 気泡からの距離 & $\mathrm{m}$ \\
\hline$\Delta P$ & : 測定差压 & $\mathrm{Pa}$ \\
\hline$\Delta P_{g}$ & : 測定区閒気相充満の差圧 & $\mathrm{Pa}$ \\
\hline$\Delta P_{l}$ & : 測定区間液相充満の差圧 & $\mathrm{Pa}$ \\
\hline$\Delta P^{*}$ & : 無次元差圧 $=\left(\Delta P-\Delta P_{g}\right) /\left(\Delta P_{l}\right.$ & $1-\Delta P_{B}$ \\
\hline$\varepsilon$ & : 局所ボイド率 & \\
\hline$\beta$ & : 気相の体積流束比 & \\
\hline$\kappa$ & : 断熱指数 & \\
\hline$\rho_{g}$ & : 気相密度 & $\mathrm{kg} / \mathrm{m}^{3}$ \\
\hline$\rho_{l}$ & : 液相密度 & $\mathrm{kg} / \mathrm{m}^{3}$ \\
\hline
\end{tabular}

\section{2. 流 動 様 式}

空気一水, 垂直管（内径 $14 \mathrm{~mm}$ ) 内気液二相上昇 流の実験を行った。実験装置および方法は前報(15)(16) と同じである、すなわち，気液の体積流量による流 れの様相の変化を高速度ビデオカメラで観察すると ともに，テスト管下流部で差圧変動を測定し，流れ の特性を調べた。その結果, 流動パターンに関し次 のような結果を得た。

気泡流 低空気流量域において，小気泡が群れを
なして流れる様相が観察された。これら小気泡の運 動は非常に不規則であった。

ㅈグ流 水流量が少なく, 空気流量が多い条件では, 小気泡の大きさが大きくなり，密集部には砲弹状の大気 泡が現九る，そして，大気泡に後続の小気泡が引き込ま れ，流れ方向に気相部（気体スラグ部）と液相部（液体 スラグ部）が形成されることが明膫に観察された。

チャーン流 スラグ流で空気流量を増加させていくと, 気体スラグ部の長さが長くなり, 液体スラグ部は短くな る. 気体スラグ部では激しい液膜の流下が認められ，液 体スラグ部には小気泡が含まれていた。

睘状流 水流量を一定に保ち，さらに空気流量を増加 させると液体スラグ部が確認できなくなり，管コア部を 気相が，管壁部を液膜が上向きに流れるようになる。上 記各流動様式の写真を図 1 亿示寸。各流動様式の差王変 動の確率密度関数の分布形状特性はこれまでの報告(7) と 同様の結果を示した。この結果については, 後記シミュ レーションの項で本モデル結果と比較, 検討している.

\section{3. モ テ ル}

3. 1 対象とする系垂值管内を上昇する等温系 気液二相流の流動様式を考える。すなわち，管入口から 液相が一定の流量で流入し, 途中の気液混合部において 一定の割合 (流量) て気相が供給され，二相流となって 下流部へ流れ，管の出口端から噴出する系をモデル化す る。なお，簡単のため，気液混合部において気液は一様 に混合されると考える。

3. 2 基礎式 等温系気液二相流の場合, 気相の 質量は保存されるので,

$$
\frac{\partial\left(\rho_{\mathrm{g}} \varepsilon\right)}{\partial \mathrm{t}}+\frac{\partial\left(\rho_{\mathrm{g}} \varepsilon U\right)}{\partial \mathrm{y}}=0
$$

ここで, \&はボイド率， $\rho_{\mathrm{g}}$ は気相の密度，Uは移流速度 である、ただし，気液混合部では，気相の供給を湧き出

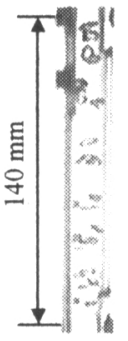

$\mathrm{J}_{\mathrm{R}}=0.022 \mathrm{~m} / \mathrm{s}$ $\mathrm{J}_{1}=0.162 \mathrm{~m} / \mathrm{s}$ Bubbly

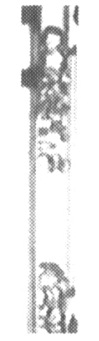

$\mathrm{J}_{\mathrm{g}}=0.074 \mathrm{~m} / \mathrm{s}$ $\mathrm{J}_{1}=0.076 \mathrm{~m} / \mathrm{s}$ Slug

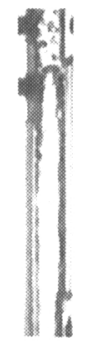

$\mathrm{J}_{\mathrm{R}}=1.067 \mathrm{~m} / \mathrm{s}$ $\mathrm{J}_{1}=0.054 \mathrm{~m} / \mathrm{s}$

Churn

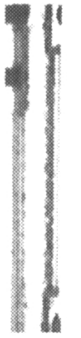

$\mathrm{J}_{\mathrm{R}}=19.02 \mathrm{~m} / \mathrm{s}$ $\mathrm{J}_{1}=0.054 \mathrm{~m} / \mathrm{s}$ Annular
Fig. 1 Snapshots of flow patterns 
し項として扱い，次式で表す。

$$
\frac{\partial\left(\rho_{\mathrm{g}} \varepsilon\right)}{\partial \mathrm{t}}+\frac{\partial\left(\rho_{\mathrm{g}} \varepsilon U\right)}{\partial \mathrm{y}}=\mathrm{q}
$$

となる.ここで, qは気液混合部単位体積当たり供給され る気相質量流量であり，

$$
q=\frac{G_{g}}{L_{m}}
$$

\section{3 モデル化}

3.3.1 流梯式のモデル化 本モデルでは，流動様式を 流れ軸方向にできるボイド率の分布パターンとして捉え る. そして管内の局所的な気相の存在を，その位置にお ける局所ボイド率に相当した体積をもつ 1 個の円筒型気 泡で表し，この気泡の流れ軸方向の分布，つまり円筒型 気泡の大きさと配列の仕方から流動様式を定めることと した. 図 2 は実際の気泡流，スラグ流，罢状流の流動様 式とモデル化された流動様式の対応である．なお，仮定 した円筒型気泡の大きさと局所ボイド率との関釈式は次 式で与えられる.

$$
\varepsilon=\left(\frac{D_{b}}{D_{p}}\right)^{3}
$$

ここで， $\mathrm{D}_{\mathrm{b}}$ は気泡径， $\mathrm{D}_{\mathrm{p}}$ は管内径である.

3.3.2 移流速度 式 (1)に含まれる移流速度Uとして, 流九場の平均速度, 同速度に相対的な気泡の上昇速度お よび先行気泡が後続気泡を引き込む速度の3つを考え， 移流速度Uはこれら速度の総和として与えられるとした。 流九場の平均速度 $\mathrm{J}_{\mathrm{f}}$ 体積流量中心速度に対して定義 される平均密度と気液の運動エネルギの総和は保存され るとの仮定から, 流れ場の平均速度は次式で与えた。

$$
J_{f}=\sqrt{\frac{\rho_{g} J_{g}^{2}+\rho_{1} J_{1}^{2}}{\rho_{g} B+\rho_{1}(1-B)}}
$$

ここで，及は気相の体積流束比であり，

$$
\beta=\frac{J_{g}}{J_{g}+J_{1}}
$$

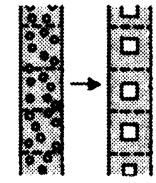

Bubbly



Slug

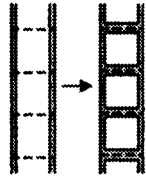

Annular
Fig.2 Modeling of flow patterns (Left: Phenomenon, Right: Model)
気泡の上昇速度 $u_{8}$ 気泡は浮力と抗力が釣り合った形 で上昇すると考える.すなわち，

$$
\frac{\pi}{4} D_{b}^{3}\left(\rho_{1}-\rho_{g}\right) g=\frac{\pi}{8} D_{b}^{2} C_{d} \rho_{1}\left(u_{g}-u_{1}\right)^{2}
$$

一方, 気液二相流の体積バランスから，

$$
\varepsilon\left(u_{g}+J_{f}\right)+(1-\varepsilon)\left(u_{1}+J_{f}\right)=J_{f}
$$

したがって，式（4），（5），（7），（8）から気 泡の上昇速度は次のように定まる。

$$
u_{g}=\varepsilon^{1 / 6}(1-\varepsilon) \sqrt{\frac{2\left(\rho_{1}-\rho_{g}\right) g D_{p}}{C_{d} \rho_{1}}}
$$

ここで， $\mathrm{C}_{\mathrm{d}}$ は抗力倸数であるが，本計算では全ての抗力 係数を 0.44 一定とした.

引き込み速度 し 行する気泡が後続の気泡を引き込む現象が見られる。こ の実際の引き込み現象にはさまざまな力が複雓に作用し ていると思われるが，ここでは簡単のため，引き込みの 主たる原因は先行気泡の後流の速度欠陷にあると考え, 最大速度欠陷を基に，その効果の及ぶ割合と影響篹囲を 定め, 引き込み速度を見積ることとした. すなわち，流 れ場の中に円柱を置いたときの 2 次元流れの実験式(17), および最大速度欠宿は 3 次元流れでは気泡からの距離の -2/3 乗に比例することが理論的にわかっているので, 最大 速度欠宿は次式で与えられることになる。

$$
u_{w \max }{ }^{\prime}=c_{1} u_{r}\left(\frac{C_{d} D_{b}}{z}\right)^{2 / 3}
$$

ここで, uは気液の相対速度, $\mathrm{c}_{1}$ は定数で, 本モデルでは $c_{1}=2.0$ とした. $c_{1}$ の影響についてはシミュレーションの 結果の項て改めて述べる. なお, 式 (10) の距離 $\mathrm{z}$ は気 泡からの距離であるが，本モデルでは管径を基準に取っ た. 式（10）に式（4）を代入すると, 最大速度欠宿は 次式で表現される.

$$
u_{w \text { max }}{ }^{\prime}=c_{1} u_{r}\left(\frac{C_{d} D_{p}}{z}\right)^{2 / 3} \varepsilon^{2 / 9}
$$

現象の観察結果によれば, 先行気泡による後続気泡の 引き込みは, 先行気泡の大きさが後続気泡よりも大きい ときのみ影著であり，先行気泡が小さいと引き込みはあ まり見られない，したがって，本モデルでは，先行気泡 の大きさが後続気泡以上のときのみ，上記の引き込み効 果を考虑することとした.

次に，引き込み効果およびその影響範囲であるが，次 式のとおり，その効果は距離と共に指数関数的に减少す

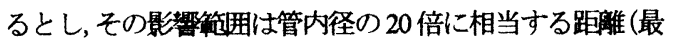
大影響範囲）とした。 


$$
\mathrm{u}_{\mathrm{w} \max }{ }^{\prime} \exp ^{-\mathrm{c}_{2} \mathrm{z}} \quad\left(\mathrm{z} \leqq 20 \mathrm{D}_{\mathrm{p}}\right)
$$

ここで, $c_{2}$ は定数であり,ここでは $\mathrm{c}_{2}=0.28 / \mathrm{D}_{\mathrm{p}}$ とおいた このパラメタの影響についても, 後のシミュレーション の項で改めて記述する，そして，最終的な引き込み速度 は, ある最大影響範囲内に存在する全ての先行気泡の引 き込み効果を後続気泡は受けるものと考えると, 式 (12) で見積られたそれぞれの速度の総和として与えられるこ とになる，なお，気液混合部では気液が一様に混合する ことから同部より上流側の引き込み速度は $0 \mathrm{~m} / \mathrm{s}$ とした。

3.3.3 気相の圧縇性効果 本モデルでは, 気液混合部に 供給される気相および管内に存在する気相は，圧力の違 いによってその体積（比体積）が変化するとしている. すなわち，等温膨張を仮定して，気液混合部および管内 に存在する気相の圧縮性を以下のとおり考虑した.

気液混合部に供給される気相

$$
\mathrm{v}=\left(\frac{\mathrm{P}_{0}}{\mathrm{P}}\right)^{1 / \mathrm{k}} \mathrm{v}_{0}
$$

ここで, $\mathrm{P}$ は気液混合部出口の絶対圧力であり, 同部から 管出口までの局所ボイド率から求めることができる， $v_{0}$ は大気圧 $\mathrm{P}_{0}$ 状態下における気液混合部単位体積当たり供 給される気相体積流量である.

管内に存在する気相 図3に示すとおり, 非圧縮性流 体として気相が移流した後, 直ちに等温変化が生じるこ ととして扱った. 最終的な気相の体積 $\mathrm{V}_{\mathrm{b} 3}$ は以下のように 与えられる。

$$
\mathrm{V}_{\mathrm{b} 3}=\left(\frac{\mathrm{P}_{1}}{\mathrm{P}_{2}}\right)^{1 / \kappa} \mathrm{V}_{\mathrm{b} 2}
$$

ここで, $\mathrm{P}_{1}, \mathrm{P}_{2}$ は移流前後の絶対圧力であり，移流前後の 局所ボイド率から求めることができる、 $V_{\mathrm{b} 2}$ は移流後の気 相の体積である。

3.3.4 液相再印分機構 ボイド率は物理的に 1 以下の正 の值をとるものである. しかし本モデルは気泡流から環 状流までの流動様式を研究对象としており，環状流では 管壁に液膜が存在する.したがって，ボイド率は 1 とな ることはない, すなわち,

$$
0 \leqq \varepsilon \leqq c_{3}
$$

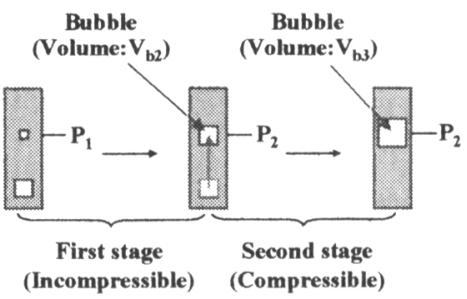

Fig. 3 Computational procedure for gas compressibility
ここで, 定数 (パラメタ) $c_{3}$ は管径に対する液膜の相対的 な厚さに関係する数值であり, 液膜厚さは時々刻々変化 するものであるが，本モデルでは液膜厚さを一定と仮定 し， $c_{3}=0.95$ とおいた。この值は，液膜の厚さが管径の 0.85 \%程度と仮定したことに相当する. なお後述のように $c_{3}$ の違いはシミュレーション結果に大きな影響を与えな い.

ボイド率が許容される最大のボイド率 $\mathrm{c}_{3}$ を越えた場合 は，下記のように下流側の局所ボイド率の值を調整する こととした。これは実際の流れでは液相が大気泡周りを 逆流し，大気泡は体積を保存しつつ流動方向に引き伸ば されることに対応する．図 4 ，図 5 に，液相再配分機構 の概念図とこれによる具体的な調整例をそれぞれ示す。 図 5 中に示した各格子内の数字はそれぞれの局所におけ るボイド率の値であり，図には下流側のボイド率の調整 手続きを示している，なお，管出口端まで調整しても調 整しきれない場合は，その状態で管外一噴出されるとし， それ以上のボイド率の調整は行わないこととした。

$$
\text { 4. シミュレーション }
$$

4. 1 離散化およひ計算条件式 (1)，（2）の 離散化にあたり，時間微分は前進差分で，刘流項は後退 差分で表わし，陽解法によってシミュレーションした。

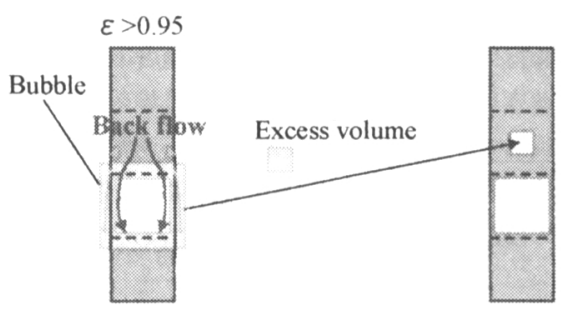

Fig.4 Liquid phase redistribution mechanism

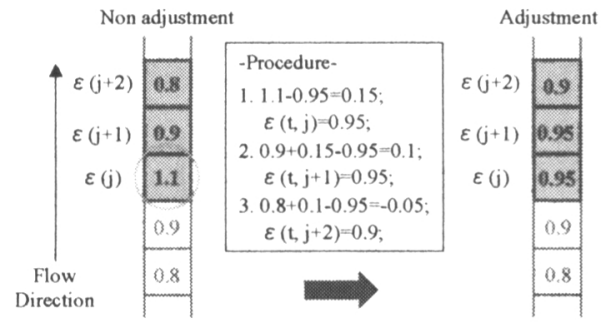

Fig.5 Computational procedure of liquid phase redistribution mechanism ( $\varepsilon>0.95$ ) 
なお，使用格子としてはスタガード格子を用い，ボイド 率はセル中心で，速度は格子上で定義した．また対流項 中の移流速度は上流側の格子上の速度を用いて近似し $U_{j+1 / 2}^{k}=U_{j}^{k}$ とした. すなわた, 式 (1)，（2）を次 式で表現した.

$$
\begin{aligned}
& \frac{\left(\rho_{g} \varepsilon\right)_{j}^{k+1}-\left(\rho_{g} \varepsilon\right)_{j}^{k}}{\Delta t}+\frac{\left(\rho_{g} \varepsilon U\right)_{j}^{k}-\left(\rho_{g} \varepsilon U\right)_{j-1}^{k}}{\Delta y}=0 \\
& \frac{\left(\rho_{g} \varepsilon\right)_{j}^{k+1}-\left(\rho_{g} \varepsilon\right)_{j}^{k}}{\Delta t}+\frac{\left(\rho_{g} \varepsilon U\right)_{j}^{k}-\left(\rho_{g} \varepsilon U\right)_{j-1}^{k}}{\Delta y}=q
\end{aligned}
$$

ここで, k は时間ステッナ゚，jは格子番男である.

なお，表 1 は本シミュレーションにおうける種々の計算条 件をまとめたものである。

\section{2 計算遇程図6に計算の手順を示す。すな} わち，先ず気液の体積流量から流九場の平均速度を見積 る. そして，管内全ての局所ボイド率が 0 となるように 初期配置を行う。次に，管内の気相の圧樎性抽上び夜相 再配分機構を考えて留所ボイド率を定める。この周所ボ イド率に基づいて移流速度を計算し，同時に，気液混合 部に供給される気相の王縮性を考虑して，そこでの気相 の体積流量を見積る。ここで，時間を 1 ステップ進め, 気相の質量保存式（16），（17）を計算し，局所ボイド 率を求める。 そして, 気相の压縮性および夜相再配分機 構を考えここの時間にお引ける夙所ボイド率を決定する. シミュレーションでは,この一連のプロセスを絽り返す。

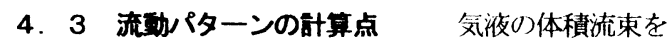
パラメタとして全40 点について計算した. 表 2 にその全 計算点を示した.

\section{4 計算結果と考案}

4.4.1 ボイド率の分布パターン 気液の体積流束によっ て流れ軸方向にさまざまなボイド率の分布パターンが現

Tablel Simulation conditions

\begin{tabular}{|c|c|}
\hline Number of all grids & $\mathrm{GN}=200$ \\
\hline Time step & $\Delta \mathrm{t}=0.001 \mathrm{~s}$ \\
\hline Girid length & $\Delta \mathrm{y}=0.014 \mathrm{~m}$ \\
\hline Initial Condition & $\varepsilon(0, \mathrm{j})=0$ \\
\hline Boundary Condition & $\begin{array}{c}\varepsilon(\mathrm{t}, 0)=0 \\
\varepsilon(\mathrm{t}, \mathrm{GN}-1)=\varepsilon(\mathrm{t}, \mathrm{GN}-2)\end{array}$ \\
\hline Gas phase & Air \\
\hline Liquid phase & Water \\
\hline Pipe I.D & $\mathrm{D}_{\mathrm{p}}=14 \mathrm{~mm}$ \\
\hline Pipe length & $\mathrm{L}=2.8 \mathrm{~m}$ \\
\hline Mixing chamber & $\begin{array}{c}0.14-0.28 \mathrm{~m} \\
\text { from pipe inlet }\end{array}$ \\
\hline Measurement point & $\begin{array}{c}2.17-0.2198 \mathrm{~m} \\
\text { from pipe inlet }\end{array}$ \\
\hline Adiabatic exponent & 1 \\
\hline
\end{tabular}

れるが，おおよそ図 7 に示すような 4 つのパターン（鋸 状波パターン, 矩形波パターン, 歪矩形波パターンおよ び一様パターン）に分類することができる．図は，表 2 の計算点番号 $9,12,14,16$ のものであり，初期条件の 影響がなくなる計算開始後 10 秒後のものである.なお, 同図は発生パターンを明瞭にするため実線で示している が，局所ボイド率の值は管径の大きさを基淮にとった離 散值である.

4.4.2 パターン発生要因 本モデルでは, 先行気泡によ る後続気泡の引き込子効果上気相の圧縮性効果，および 液相再配分機構を考慮しているが，矩形波パターンは液 相が気相周りを逆流する液相再配分機構により発生する

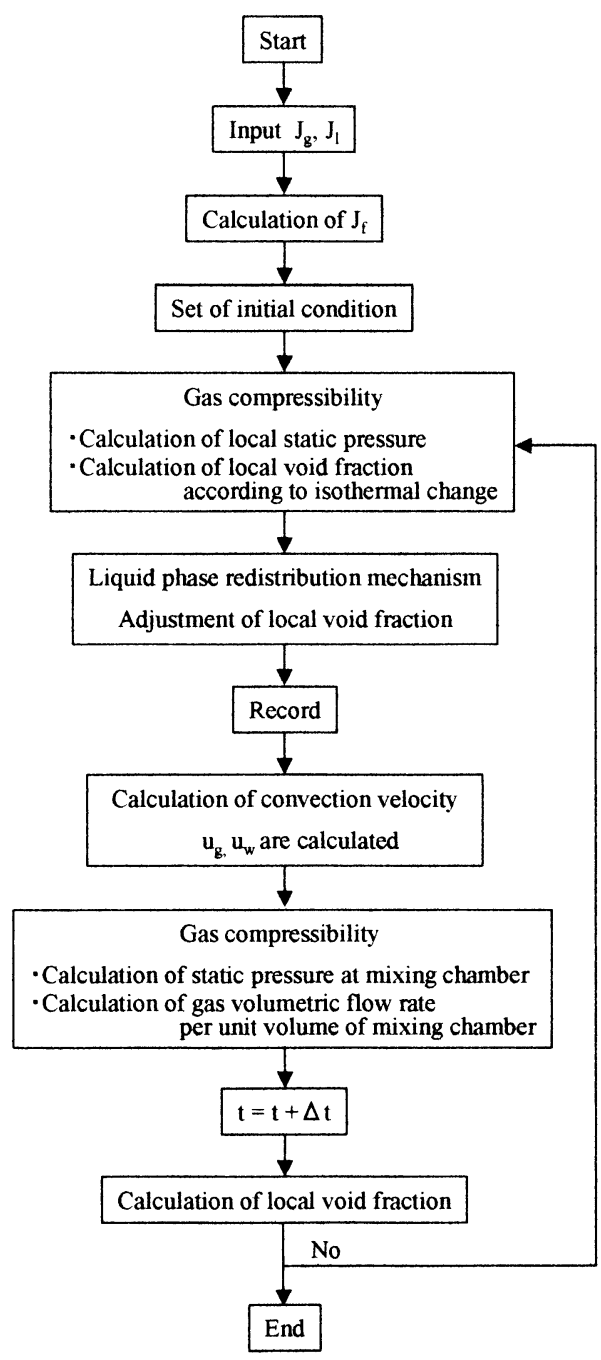

Fig.6 Flow chart of simulation 
ものであり，この抎散効果によって流れ軸方向に気相分 布密度の一様化が促進される，一方，先行気泡の引き込 子效果および気相の圧縮性効果は流れ軸方向に気相分布 密度の非一様化を促進するものである．そして，どのパ ターンが現れるかは, 移流速度（気相の管内滞在時間） と気相の体積流量（供給気相体積流束）との関係から決 まる。

\subsection{3 モデルの検証}

確率密度関数(PDF) ボイド率の分布パターンと流動 様式とを対応させるため，気液混合部から $1.890 \mathrm{~m} \sim 1.918$ $\mathrm{m}$ の測定区間で平均局所ボイド率を計算し，そのPDFを 求めた. ところで, 従来の研究(4)ー(7)によれば, 周所ボイド 率変動および圧力変動の PDF 分布形状特性は類似してお り，流動様式ごとに次のような特性のあることが知られ ている.

気泡流：低ボイド率領域に 1 つピークをもつ分 布特性.

スラグ流：低ボイド率領域及び高ボイド率領域に それぞれ 1 つのピークをもつ分布特性. 低ボイド率領域のピークの確率が高ボイ ド率領域のピークの確率より高い.

チャーン流：スラグ流と同じ分布特性.ただし， 低ボイド率領域のピークの確率が高ボイ ド率領域のピークの確率より低い.

環状流：高ボイド率領域に 1 つのピークをもつ分布特 性.

図8に本モデル結果と実験結果とを示すが，これによれ ば，鋸状波パターンは気泡流，矩形波パターンはスラグ 流，歪矩形波パターンはチャーン流，一様パターンは舆 状流に対応すると見なすことができ，本モデルが流動様 式の基本的な特性を捉えていると言ってよいであるう。 なお，モデル結果は圧力損失成分中，水頭損失成分のみ を考慮したものである.

流動様式楾図との比較 表 2 に示した全計算点につい

Table2 Imput data (Unit: $\mathbf{m} / \mathbf{s}$ )

\begin{tabular}{|c|c|c|c|c|c|c|c|c|}
\hline No. & $\mathrm{Jg}_{\mathrm{g}}$ & $J_{1}$ & No. & $\mathrm{Jg}_{\mathrm{g}}$ & $J_{1}$ & No. & $\mathrm{J}_{\mathrm{g}}$ & $\mathrm{J}_{1}$ \\
\hline 1 & 0.02 & 0.03 & 15 & 5.0 & 0.08 & 29 & 0.8 & 0.8 \\
\hline 2 & 0.05 & 0.03 & 16 & 10.0 & 0.08 & 30 & 2.0 & 0.8 \\
\hline 3 & 0.1 & 0.03 & 17 & 0.02 & 0.3 & 31 & 5.0 & 0.8 \\
\hline 4 & 0.3 & 0.03 & 18 & 0.05 & 0.3 & 32 & 10.0 & 0.8 \\
\hline 5 & 0.8 & 0.03 & 19 & 0.1 & 0.3 & 33 & 0.02 & 3.0 \\
\hline 6 & 2.0 & 0.03 & 20 & 0.3 & 0.3 & 34 & 0.05 & 3.0 \\
\hline 7 & 5.0 & 0.03 & 21 & 0.8 & 0.3 & 35 & 0.1 & 3.0 \\
\hline 8 & 10.0 & 0.03 & 22 & 2.0 & 0.3 & 36 & 0.3 & 3.0 \\
\hline 9 & 0.02 & 0.08 & 23 & 5.0 & 0.3 & 37 & 0.8 & 3.0 \\
\hline 10 & 0.05 & 0.08 & 24 & 10.0 & 0.3 & 38 & 2.0 & 3.0 \\
\hline 11 & 0.1 & 0.08 & 25 & 0.02 & 0.8 & 39 & 50 & 3.0 \\
\hline 12 & 0.3 & 0.08 & 26 & 0.05 & 0.8 & 40 & 10.0 & 3.0 \\
\hline 13 & 0.8 & 0.08 & 27 & 0.1 & 0.8 & & & \\
\hline 14 & 2.0 & 0.08 & 28 & 0.3 & 0.8 & & & \\
\hline
\end{tabular}

て，そこで現れるパターンの局所ボイド摔を計算し，そ の確率密度関数の分布形状特性から流九軸方向のボイド 率の分布パターンを判定してみた，図9ははその判定結果 であり, Mishima-Ishii の流動様烒楾因 ${ }^{(3)} に$ にプロットしたも のである、この結果を見ると，ボイド率の分布パターン の僄移と流動様式楾图の境界線とが比較的一致しており 簢易ながら本モデルは流動様式とその遷移をよく説明す るものであることがわかる.

摩擦損失特性 本シミュレーション結果に，原子炉冷 却系統の流動解析でよく用いられる TRAC-PF1MODI コ 一ド(18)の液相による壁面摩擦損失の相関式

$$
\left(\frac{\mathrm{dp}}{\mathrm{dy}}\right)_{\mathrm{f}}=\frac{2 \mathrm{f}}{\mathrm{D}_{1}}(1-\varepsilon) \rho_{1}\left|\mathrm{U}_{1}\right| \mathrm{U}_{\mathrm{l}}
$$

ここで， $\left(\frac{\mathrm{dp}}{\mathrm{dy}}\right)_{\mathrm{f}}$ は一相流の壁面摩擦損失公配（本モデル では液相のみを考惫）， $\mathrm{D}_{1}$ は水力学的等価直径， $\mathrm{U}_{1}$ は液 相絶対速度，fは摩擦係数であり，流孔場を乱流と仮定し てレイノルズ数 $\operatorname{Re}$ の関数として以下のとおり与えられる.

$$
\mathrm{f}=0.046 \operatorname{Re}^{-0.2}
$$
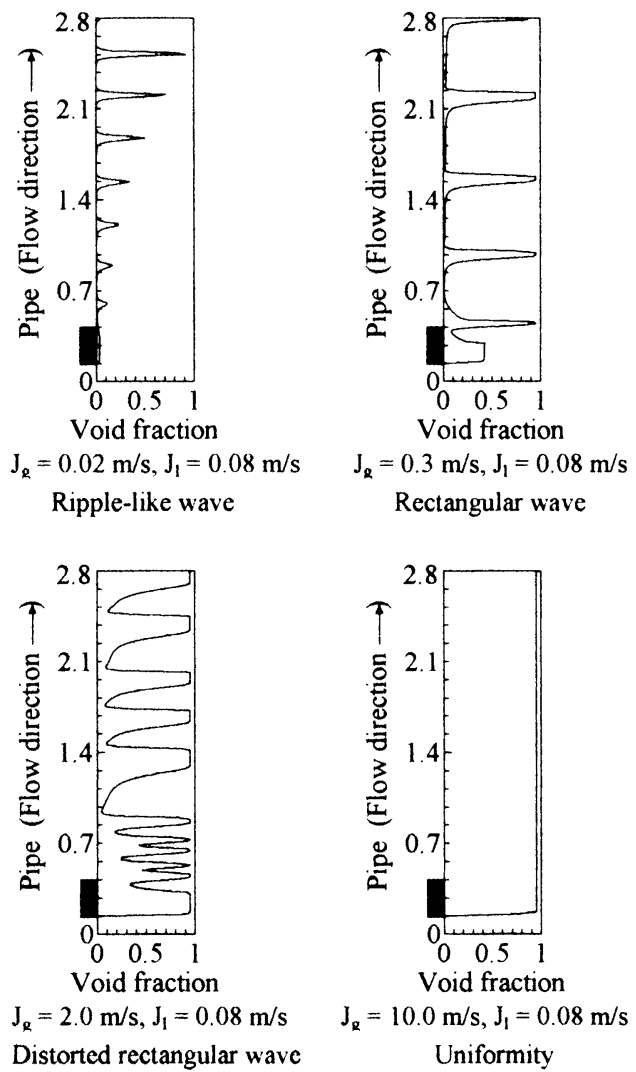

Fig.7 Void wave patterns 
を導入することにより気液一相活心摩擦損失を推定し， Lockhart-Martinelli ${ }^{(19)} の$ 相関 (L-M 相関) と比較してみた. その結果が困 10 である.プロットしたデータは, 液相の 体積流束が $0.3 \mathrm{~m} / \mathrm{s}$ 以上の場合のものであるが，L-M相関 の近似表現である Chisholmの式(20)の傾问をとらえており， これからも本モデルで用いた流れ場の平均速度及び夜相 絶対速度の值が物理的におかしなものではないことが見 て取れる.

\subsection{4 モデルの迨用限界と挔張性}

本モデルの適用限界として，先ず，管内径の問題があ る. 本モデルでは，気相の移流速度の見積りにおいて慣 性力, 壁面摩擦力, 表面張力等を無視している.したが って，本モデルは基本的に重力が強く支配する系に対し てのみ適用可能であり, 適用可能な管径の下限值はフル 一ド数 (Fr) とウェーバ数 (We) との関係から以下のと おり考えると,


Ripple-like wave (Upper) Bubbly (Lower)
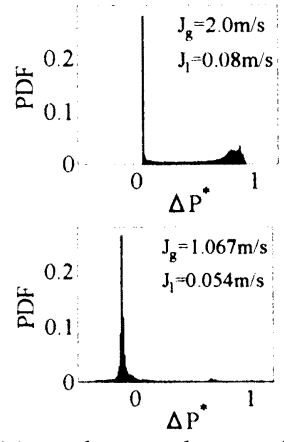

Distorted rectangular wave (Upper) Churn (Lower)
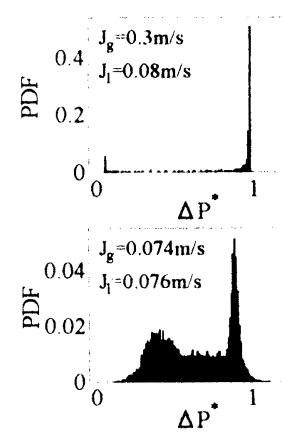

Rectangular wave (Upper) Slug (Lower)
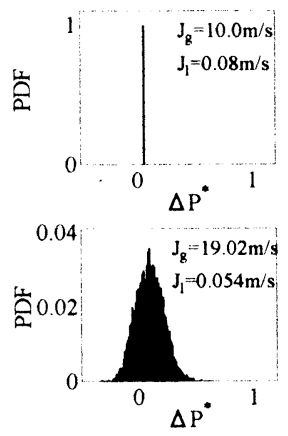

Uniformity (Upper) Annular (Lower)

$$
\begin{array}{ll}
\Delta \mathrm{P}^{*}=\left\{\rho_{\mathrm{g}} \varepsilon+\rho_{1}(1-\varepsilon)\right\} \mathrm{gH} /\left(\Delta \mathrm{P}_{1}-\Delta \mathrm{P}_{\mathrm{g}}\right) & \text { Simulation } \\
\Delta \mathrm{P}^{*}=\left(\Delta \mathrm{P}-\Delta \mathrm{P}_{\mathrm{g}}\right) /\left(\Delta \mathrm{P}_{1}-\Delta \mathrm{P}_{\mathrm{g}}\right) & \text { Experiment }
\end{array}
$$

Fig.8 PDF characteristics of differential pressure fluctuation. (Upper: Simulation, Lower: Experiment)

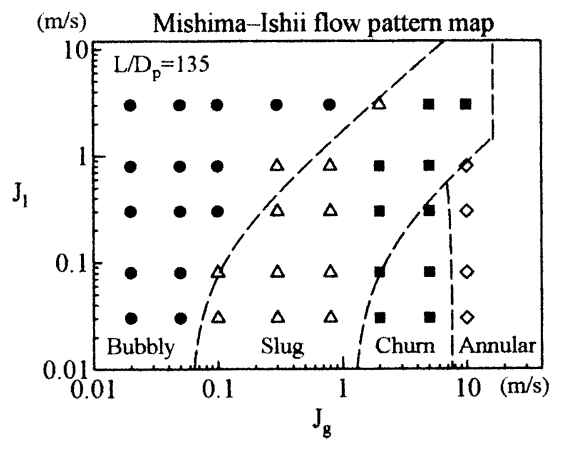

Symbols

: Ripple-like wave, $\triangle$ : Rectangular wave

: Distorted rectangular wave, $\diamond$ : Uniformity

Fig.9 Comparison between void wave pattern map and Mishima-Ishii flow pattern map

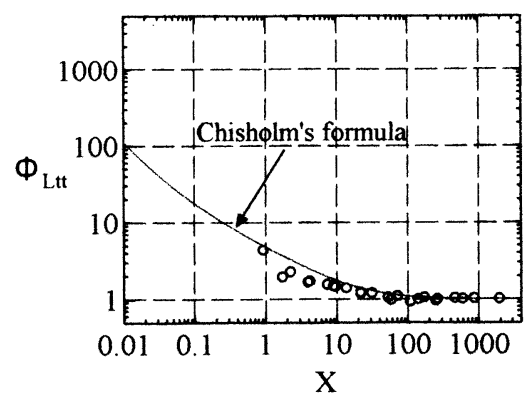

Chisholm's formula

$\Phi_{\mathrm{Ltt}}{ }^{2}=1+21 / \mathrm{X}+1 / \mathrm{X}^{2}$

Fig.10 Estimated friction loss

$$
\begin{aligned}
& \frac{W e}{F r}=\frac{\rho_{1} D_{p}^{2} g}{\sigma}>10 \\
& D_{p}>\Phi 8.6 \mathrm{~mm}
\end{aligned}
$$

一方，上限值について明確な限界を定めることは難しく 今後の研究課題であるが，本モデルは先行気泡が後続気 泡を引き込む速度の見積りなどにおいて管内径の大きさ を基準寸法としていることから，管内径が甚だしく大き い場合には適用できないと思われる．しかし，管内径の 大きさが $28 \mathrm{~mm}$ の場合についてシミュレーションを行い， Mishima-Ishii 流動様式線図と比較したところ,よく一致す ることを確認しており, 少なくとも管内径が約 $26 \mathrm{~mm}$ 程 度までは十分適用可能と思われる. なお本モデルには 3 つの定数 $\mathrm{c}_{1}, c_{2}, c_{3}$ が含まれているが，上記の $\mathrm{D}_{\mathrm{p}}=28 \mathrm{~mm}$ の計算においても本報で用いたのと同じ值を用いた. こ 
れら定数のうち $c_{1}, c_{1}$ 引き込み速度 $u_{w}$ に関係するもの である. $c_{1}$ を大きく $c_{2}$ を小さくれば先行気泡の引き込 み効果が大きくなって気相分布密度の非一様化が促進さ れるが，それに伴い液相再配分機棈による気相分布密度 の部分的な一様化も促進される．また，引き込み速度の 増加は気相の移流速度 U を大きくすることになるから気 相の管内滞在時間が短くなる.したがって，たとえ先行 気泡の引き込み効果が大きくなったとしても同先行気泡 の管内滞在時間が短くなることから，結果的に十分に後 続気泡の引き込みが行われず, シミュレーション結果に 大きな影㮣は現れない，次に液相再配分機構の閶值を与 える $c_{3}$ は気体スラグや程状流における液膜厚さに関係し 本モデルのように管径基準のセル中に単一の気泡を仮定 した単純化モデルにおいても，甚だしく小さくすること はスラグ流や場合によっては気泡流においても不具合を 生じる可能性があり，妥当ではない，一例として c の值 を 0.8 (液膜岸さが管径の $3.58 \%$ 程度) として計算したと ころ, 矩形波パターンから歪矩形波パターンへの遷移及 び歪矩形波パターンから一様パターンへの遷移が気相の 体積流束が小さい方向へ若干移動するが，大きな差異は 見られなかったことを確認している(19).

一方，モデルの拡張性に関してであるが，本モデルで 取り入れた管径基準による物理量の評価方法を改良する ことにより，大口径管の場合にも適用可能であると思わ れる. また，本モデルは気相流束が保存される気液等温 系を対象に構筑されてはいるが，若干の工夫を加えるこ とにより，沸騰二相流系にも拡張可能と考えられる.さ らに，本モデルを拡張，適用して，流動様式と深い関連 をもつ気液二相流の他の特性，例えば分岐管による相分 離特性 (21)(2)などを説明できる可能性がある。

\section{5.まとめ}

等温系気液二相流の気泡流から睘状流までの流動様式 およびその僄移を，統一的な考え方に基づいてできる简 易なモデルを棈築した．本モデルは，流動様式を流れ軸 方向にできるボイド率の分布パターンとして捉え，異な った 4 つのパターンの出現と遷移が流動様式とその蹗移 に対応し, Mishima-Ishii 流動様式線図とよく一致した。 ま た，本モデルによる PDF 分布形状特性は実験による特性 とほほ一致した，一方，本モデルを用いて求めた摩察損 失特性はChisholm の式の傾向をよく表したことから，本 モデルで用いた值が物理的に甚だしくおかしなものでは ないことを確認できた，これらの結果から，垂值管内二 相流の流動様式を定めている要因は，気相の移流速度，
先行気泡による後続気泡の引き込み効果，気相の圧綰性 および夜相再分配機棈であると考えられる.

\section{文孛}

(1) Baker, O., Simultaneous Flow of Oil and Gas, Oil Gas J., 53 (1954), 185-195.

(2) Griffith, P. and Wallis, G. B., Two-Phase Slug Flow, Trans. ASME Ser. C, (1961), 307-320.

(3) Mishima, K. and Ishii, M., Flow Regime Transition Criteria for Upward Two-Phase Flow in Vertical Tubes, Int. J. Heat Mass Transfer, 27-5 (1984), 723-737.

(4) Jones, $J_{R}$. O. C. and Zuber, N., The Interrelation between Void Fraction Fluctuations and Flow Patterns in Two-Phase Flow, Int. J. Multiphase Flow, 2 (1975), 273-306.

(5) Vince, M. A. and Lahey, R. T., On the Development of an Objective Flow Regime Indicator, Int. J. Multiphase Flow, 8-2 (1982), 93-124.

(6) Hubbard, M. G. and Dukler, A. E., The characterization of Flow Regimes for Horizontal Two-Phase Flow, Proc. Heat Transf. Fluid Mech. Inst., (1966), 100-121

(7) Matsui, G., Automatic Identification of Flow Regimes in Vertical Two-Phase Flow Using Differential Pressure Fluctuations, Nucle. Eng. Des., 95(1986), 221-231.

(8) Franca, F., Acikgoz, M., Lahey, R. T. and Clausse, A., The Use of Fractal Techniques for Flow Regim Identification, Int. J Multiphase Flow, 17-4 (1991), 545-552

(9) Moissis, R. The Transition from Slug to Homogeneous Two-Phase Slug Flow, Trans. ASME Ser. C, (1963), 366-370.

(10) Yabe, T. and Xiao, F., Simulation Technique for Dynamical Evahuation Processes, Nucl. Eng. Des., 115(1995), 45-53.

(11) Osher, S. and Sethian, J. A., Fronts Propagating with Curvature-Dependent Speed : Algorithms Based on Hamilton-Jacobi Formulations, J. Comput. Phys., 79 (1988) $12-49$.

（12）功刀资彰，機論，63-609, B (1997)，1576-1584

(13) Trapp, J. A. and Mortensen, G. A., A Discrete Particle Model for Bubble-Slug Two-Phase Flows, J. Comp. Phys., 107 (1993), 367-377.

(14) Tomiyama, A., Zum, I., Higaki, H. and Sakaguchi, T., A Three-Dimensional Particle Tracking Method for Bubbly Flow Simulation, Nuclear Eng. Des., 175 (1997), 77-86.

（15）伊藤浩二, 宮崎大輔，庄司正弘，機論，68-671，B (2002), 2079-2085

（16）伊藤浩二, 東京大学学位論文, (2002)

(17) 日本機械学会編，機械工学便筧 基礎偏 A5 流体工学, (1986), 68-69.

(18) Safety Code Development Group, TRAC-PF1/MODI: An Advanced Best-Estimate Computer Program for Pressurized Water Reactor Thermal-Hydraulic Analysis, Los Alamos National Laboratory Report, NUREG/CR-3858, LA-10157MS, (1986)

(19) Lockhart, R W. and Martinelli, R. C., Proposed Correlation of Data for Isothermal Two-Phase, Two-Component Flow in Pipes, Chem. Eng. Prog., 45-1 (1949), 39-48.

(20) Chisholm, D., A Theoretical Basis for The Lockhart-Martinelli Correlation for Two-Phase Flow, Int. J. Heat Mass Transfer, 10 (1967), 1767-1778.

(21) Wang, S.F. and Shoji, M., Nonlinear Analysis on Differential Pressure of Two-phase Flow Through a T-junction, Int. $J$. Heat Mass Transfer, 46 (2003), 1519-1528.

(22) Wang, S. F. and Shoji, M., Fluctuation Characteristics of Two-Phase Flow Splitting at a Vertical T-junction, Int. J. Multiphase Flow, 28-12(2002), 2007-2016. 